\title{
The Metabolism of Propane in Rhodococcus rhodochrous PNKb1
}

\author{
By N. R. WOODS AND J. C. MURRELL* \\ Department of Biological Sciences, University of Warwick, Coventry CV4 7AL, UK
}

(Received 4 January 1989; revised 27 February 1989; accepted 28 April 1989)

\begin{abstract}
A bacterium that utilized propane as a sole carbon source was isolated from soil and identified as a strain of Rhodococcus rhodochrous. Of the $n$-alkanes tested $\left(\mathrm{C}_{1}-\mathrm{C}_{8}\right)$ it grew only on propane, and it was not capable of growth on alkenes. The organism grew on most of the potential intermediates of propane metabolism and simultaneous adaptation studies showed that it could oxidize both terminal and sub-terminal intermediates. Assays of enzyme activities in cell-free extracts revealed elevated levels of enzymes of both terminal and sub-terminal pathways in propane-grown cells. The initial propane-specific oxygenase activity was measured by its ability to co-oxidize propene to epoxypropane. This oxygenase system was investigated in terms of its inhibitor profile and was compared with $n$-alkane oxygenase systems described in the literature. On the basis of the comparison, the oxygenase appears to be of a type not previously reported.
\end{abstract}

\section{INTRODUCTION}

The ability of micro-organisms to utilize propane as a sole carbon source is well documented (Perry, 1980). Such organisms belong mainly to the Corynebacterium-Mycobacterium-Nocardia complex, a loosely defined group containing other genera such as Rhodococcus, Brevibacterium and Arthrobacter (Klug \& Markovetz, 1971; Perry, 1980). The understanding of the physiology and biochemistry of this group of organisms, particularly regarding their metabolism of gaseous alkanes, is somewhat limited. There appears to be a general opinion that propane is metabolized principally by a sub-terminal oxidation pathway via acetone (Fig. 1) (Perry, 1968, 1980). Much of the evidence to support this opinion is based on growth substrate specificities, product excretion and simultaneous adaptation studies, all techniques that should be interpreted with caution (Dagley \& Chapman, 1971). Recently Stephens \& Dalton (1986) reassessed much of the data and concluded that terminal oxidation of propane (Fig. 1) may be more significant than was previously supposed. Other recent reports (Babu \& Brown, 1984; MacMichael \& Brown, 1987) have also suggested that terminal oxidation of propane may be occurring in at least some gaseous alkane utilizers.

Measurements of enzyme activities within cell-free extracts of alkane-grown organisms are lacking in many of these studies (but see Taylor et al., 1980; Van Ginkel et al., 1987) and investigation of the initial oxygenase in cell-free systems has only recently been attempted (Patel et al., 1983).

This paper reports on the isolation and investigation of a Rhodococcus sp. that grows on propane, with reference to propane-specific enzyme activities in cell-free extracts and the nature of the propane oxygenase enzyme system.

\section{METHODS}

Isolation of $R$. rhodochrous PNKb1. Soil and water samples were obtained from both environments known to have been exposed to $n$-alkanes and environments apparently having no such exposure. Samples were suspended in $10 \mathrm{ml}$ of sterile mineral salts (MS) medium (Whittenbury et al., 1970). Suspensions were allowed to clear slightly and $100 \mu \mathrm{l}$ of supernatant was used to inoculate $50 \mathrm{ml}$ of MS medium, in a $250 \mathrm{ml}$ Quickfit flask, to which $0.5 \mathrm{~g}$ $\mathrm{NH}_{4} \mathrm{Cl}^{-1}, 0.5 \mathrm{~g} \mathrm{KNO}_{3} 1^{-1}$ and a vitamin supplement (Gest et al., 1983) had been added (ANMSV medium). The flask was sealed with a 'Suba seal' and gassed with propane to give $50 \%(\mathrm{v} / \mathrm{v})$ propane in air, and then incubated at 
$30^{\circ} \mathrm{C}$ on an orbital shaker until significant turbidity developed. Serial dilutions of the culture were spread onto ANMSV agar plates and single colonies then streaked onto ANMSV agar plates. Plates were incubated at $30^{\circ} \mathrm{C}$ in a $50 \%(\mathrm{v} / \mathrm{v})$ propane/air atmosphere. Purity was checked by several passages through liquid medium and serial dilutions onto ANMSV plates followed by rigorous microscopic examination.

A large number of different propane-utilizing bacteria were also obtained using a continuous enrichment procedure in a one-litre fermenter vessel sparged with a $50 \%(\mathrm{v} / \mathrm{v})$ propane in air gas mixture at $120 \mathrm{ml} \mathrm{min} \mathrm{m}^{-1}$. Temperature $\left(30^{\circ} \mathrm{C}\right), \mathrm{pH}(6.8)$ and agitation were controlled and dilution rates of between $0.014 \mathrm{~h}^{-1}$ and $0.04 \mathrm{~h}^{-1}$ were employed.

Growth studies. Growth of $R$. rhodochrous PNKbl was routinely achieved using AMS medium (MS medium plus $1 \mathrm{~g} \mathrm{NH}_{4} \mathrm{Cl}^{-1}$ ) in $250 \mathrm{ml}$ Quickfit flasks. These flasks were sealed with 'Suba seals' and $50 \mathrm{ml}$ of air replaced with $50 \mathrm{ml}$ of gaseous substrate (alkane, alkene or alkyne). Volatile liquid substrates were supplied at 0.1 or $0.05 \%(\mathrm{v} / \mathrm{v})$ into similar sealed flasks and solid substrates were supplied at $0.1 \%(\mathrm{w} / \mathrm{v})$. Where large volumes of alkane-grown cells were required, growth was batchwise in an $\mathrm{LH} 500$ series fermenter of 1.71 working volume, fed with propane $\left(50 \%, \mathrm{v} / \mathrm{v}\right.$, in air) at $60 \mathrm{ml} \mathrm{min}^{-1}$, stirred at $800 \mathrm{r}$.p.m. and operated at constant $\mathrm{pH}(6.8)$ and temperature $\left(30^{\circ} \mathrm{C}\right)$.

Measurement of cell density. Cell density was routinely measured as $\mathrm{OD}_{540}$ using a Pye Unicam SP1800 spectrophotometer. Dry weights (established using a filtration/drying method: Gerhardt, 1981) were estimated from a standard curve of $\mathrm{OD}_{540}$ versus dry weight.

Preparation of cell suspensions. Cultures from flasks or fermenters were centrifuged at $20000 \mathrm{~g}$ for $10 \mathrm{~min}$ at $4{ }^{\circ} \mathrm{C}$. Cell pellets were washed in $30 \mathrm{ml}$ of ice-cold buffer $(20 \mathrm{mM}-\mathrm{Tris} / \mathrm{HCl}, \mathrm{pH} 6.8)$ and centrifuged as before. The cell pellets were then resuspended in the same buffer to an $\mathrm{OD}_{540}$ of between 20 and 40 (4.6 and $11.6 \mathrm{mg}$ dry weight cells $\mathrm{ml}^{-1}$ ).

Preparation of cell-free extracts. Cells, prepared as above, were disrupted by three passages through a precooled French pressure cell operated at $138 \mathrm{MPa}$. Disrupted cells were then centrifuged at $30000 \mathrm{~g}$ for $10 \mathrm{~min}$ at $4^{\circ} \mathrm{C}$ to remove any unbroken cells and membrane debris.

Oxygen electrode assays. The ability of $R$. rhodochrous PNKbl to oxidize a variety of substrates was tested by measuring the stimulation of oxygen uptake on addition of the substrate to cell suspensions contained in a Clarktype oxygen electrode. Assays were done at $30^{\circ} \mathrm{C}$ in $2.9 \mathrm{ml}$ of $20 \mathrm{mM}$-phosphate buffer, $\mathrm{pH} 6.8$. Air-saturated buffer was placed in the reaction chamber, the plunger inserted and the system allowed to equilibrate. Cell suspension $(50 \mu \mathrm{l})$ was then added by syringe and the endogenous rate of oxygen uptake was measured. Substrate $(50 \mu \mathrm{l})$ was then injected and any stimulation in oxygen uptake was recorded. Rates of oxygen uptake were corrected for endogenous rate and expressed as $\mathrm{nmol} \mathrm{O}_{2} \mathrm{~min}^{-1}$ ( $\mathrm{mg}$ dry weight of cells) ${ }^{-1}$. The dissolved oxygen concentration of air-saturated buffer was calculated using the method of Robinson \& Cooper (1970).

Gaseous substrates were prepared by degassing $5 \mathrm{ml}$ distilled water under vacuum then passing the contents of a football bladder inflated with the gas through the water. Liquid alkanes and other relatively insoluble substrates were prepared as saturated solutions. The final concentrations of these substrates were calculated using the data of McAuliffe (1966). Substrates readily soluble in water were prepared as $2 \mathrm{mM}$ solutions giving a final concentration in the assay of $33.3 \mu \mathrm{M}$.

Enzyme assays. (a) Alcohol/aldehyde dehydrogenase (EC 1.1.1.-). This was measured spectrophotometrically as an NAD ${ }^{+}$-linked activity using a Pye Unicam SP1800 spectrophotometer at $340 \mathrm{~nm}$. Assays were done in a total volume of $1 \mathrm{ml}$. The cuvette contained, in $20 \mathrm{mM}-\mathrm{Tris} / \mathrm{NaOH}, \mathrm{pH} 10 \cdot 0,0.2 \mu \mathrm{mol} \mathrm{NAD}+$ and $0 \cdot 1-1.0 \mathrm{mg}$ of protein extract (enough to give a linear rate for more than $5 \mathrm{~min}$ ). Cuvettes were allowed to equilibrate for $1 \mathrm{~min}$ at $30^{\circ} \mathrm{C}$ before the reaction was initiated by the addition of $10 \mu \mathrm{mol}$ alcohol or aldehyde.

(b) Propionyl-CoA synthetase (EC 6.2.1.-). This was measured by the determination of propanoate-dependent sulphydryl CoA disappearance using the method of Grunert \& Phillips (1951).

(c) Ketone oxygenases. Acetone and acetol oxygenase activities were measured by substrate-dependent stimulation of oxygen uptake in a Clark-type oxygen electrode using the method of Hartmans \& de Bont (1986).

(d) Acetol dehydrogenase (EC 1.1.1.-). This was measured spectrophotometrically using an NAD(P)+-linked assay as described by Taylor et al. (1980).

(e) Isocitrate lyase (EC 4.1.3.1). The methods used were those of Dixon \& Kornberg (1959), and Reeves et al. (1971).

( $f$ ) Propane oxygenase. Assays were performed in $2 \mathrm{ml}$ gas chromatography (GC) vials in a total volume of $0.25 \mathrm{ml}$. Sufficient $20 \mathrm{~mm}$-Tris $/ \mathrm{HCl}, \mathrm{pH} 6.8$, to give a final assay volume of $0.25 \mathrm{ml}$ was placed in a $\mathrm{GC}$ vial along with 1-5 mg of protein from a cell-free extract. The vial was sealed and preincubated at $30^{\circ} \mathrm{C}$ for $30 \mathrm{~s}$ in a shaking water bath $(250$ r.p.m.). NADH $(1 \mu \mathrm{mol})$ was added and $0.9 \mathrm{ml}$ of air was removed and replaced with $0.9 \mathrm{ml}$ of propene. The vial was returned to the water bath and $5 \mu 1$ samples were removed every 5 min and analysed on a Pye Unicam gas chromatograph fitted with a $1.5 \mathrm{~m} \times 2.3 \mathrm{~mm}$ glass column packed with Poropak $Q$. The column was run isothermally at $180^{\circ} \mathrm{C}$ with nitrogen $\left(30 \mathrm{ml} \mathrm{min}^{-1}\right)$ as carrier gas. Output from the gas chromatograph was linked to a reporting integrator (Hewlett Packard) that had been calibrated with standard solutions. Rates were expressed as nmol 1,2-epoxypropane formed $\mathrm{min}^{-1}$ (mg protein) ${ }^{-1}$. Whole-cell oxygenase activity was measured as above (omitting NADH) but using $12 \mu \mathrm{l}$ cell suspension plus $238 \mu \mathrm{l}$ buffer. 
Inhibitor studies. Potential inhibitors were made up as $100 \mathrm{mM}$ solutions except $\mathrm{CO}$ and $\mathrm{C}_{2} \mathrm{H}_{2}$, which were made up as saturated solutions having concentrations of $1 \mathrm{mM}$ and $44 \mathrm{mM}$, respectively (Stirling, 1978). They were added to vials, to give a final concentration as indicated in Table 3, before addition of the substrate. Control vials lacked inhibitor.

For all whole-cell oxidation studies and preparation of cell-free extracts for use in enzyme assay work, $R$. rhodochrous $\mathrm{PNKbl}$ was harvested at culture cell densities $\left(\mathrm{OD}_{540}\right)$ of $0 \cdot 7$, i.e. during the late exponential phase of growth. All enzyme activities reported are mean values after at least three determinations.

Polyacrylamide gel electrophoresis. The method was based on that of O'Farrell (1975) and used a discontinuous buffer system as described by Laemmli (1970). The resolving gel was prepared in $3.0 \mathrm{M}-\mathrm{Tris} / \mathrm{HCl}, \mathrm{pH} 8.8$, and the stacking gel in $0.5 \mathrm{M}$-Tris/ $\mathrm{HCl}, \mathrm{pH} \mathrm{6.8}$. The running buffer was Tris/glycine ( $25 \mathrm{~mm}$-Tris base, $129 \mathrm{~mm}-\mathrm{glycine}$ ). Gels were formed from 10 to $30 \%(\mathrm{w} / \mathrm{v})$ exponential gradients of acrylamide. Electrophoresis was done at a constant current of $15 \mathrm{~mA}$. The stacking gel, resolving gel and running buffer contained sodium dodecyl sulphate (SDS) at $0 \cdot 1 \%(\mathrm{w} / \mathrm{v})$ and 2-mercaptoethanol at $1 \mathrm{mM}$. Cell-free extracts for SDS-PAGE were boiled for $5 \mathrm{~min}$ in sample buffer (125 mM-Tris/HCl, pH 6.8, sucrose $10 \%, \mathrm{w} / \mathrm{v}$, and SDS $4 \%$, w/v). Prior to loading, samples were mixed with bromophenol blue tracking buffer $(10 \mu l, 0.1 \%$, w/v, bromophenol blue per $0.5 \mathrm{ml}$ sample). Gels were stained for $5 \mathrm{~h}$ in $0.1 \%(\mathrm{w} / \mathrm{v})$ Coomassie Blue $\mathrm{R}$ in $10 \%(\mathrm{v} / \mathrm{v})$ acetic acid and $40 \%(\mathrm{v} / \mathrm{v})$ methanol. They were destained in the same solvent for $2-4 \mathrm{~h}$.

Chemicals. Gases were of the purest grade available (greater than $99 \%$ ) obtained from British Oxygen Co., Matheson Gases and Cambrian Chemicals. All other compounds, inhibitors, substrates, media components, etc. were obtained from Sigma, Aldrich, BDH and Fisons Scientific Apparatus.

\section{RESULTS}

\section{Isolation and characterization of the propane-utilizing strain}

Over 80 strains of Gram-positive propane-utilizing bacteria were isolated using both batch and continuous enrichment techniques. All of the organisms isolated had morphologies consistent with their being members of the Corynebacterium-Mycobacterium-Nocardia complex. Organisms were isolated from terrestrial and aquatic environments with and without evidence of $n$-alkane contamination. Strains showed varying degrees of specificity towards ethane, propane and butane as growth substrates, some growing on all three, others only on two or one.

One of these strains, designated PNKb1, was studied in detail since it grew rapidly on propane and, unlike many other isolates, did not flocculate in liquid culture. Colonies on nutrient agar and propane/AMS agar plates were pink in colour and showed a mycelial morphology when viewed under low magnification $(\times 30)$. The organisms were non-motile, Gram-positive rods that were catalase-positive, non-sporeforming and showed oxidative metabolism of glucose. On entering the stationary phase of growth, cells underwent a rod to coccus transition. These characteristics suggested that the strain was a Rhodococcus or Nocardia sp. A more complete identification was performed by NCIMB Ltd (Aberdeen, UK), who assigned $\mathrm{PNKb} 1$ to the species Rhodococcus rhodochrous.

Of the $n$-alkanes tested (i.e. methane to octane) $R$. rhodochrous PNKb1 grew only on propane. The unsaturated hydrocarbons ethene, propene and butene were not growth substrates but ethyne and propyne were (see de Bont \& Peck, 1980). Other growth substrates included acetate, pyruvate, succinate, glucose and nutrient broth. Batch culture doubling-times of $R$. rhodochrous PNKbl on propane and pyruvate were 8 and $3 \mathrm{~h}$, respectively.

\section{Growth on potential intermediates of propane metabolism}

$R$. rhodochrous PNKbl was tested for the ability to grow on the potential intermediates of propane metabolism (see Fig. 1). Rapid growth occurred on propan-1-ol, propanal, propanoate, propan-2-ol, propanone (acetone) and hydroxypropanone (acetol). Propanal and propanone appeared to be toxic at $0.1 \%(\mathrm{v} / \mathrm{v})$ and were supplied at $0.05 \%(\mathrm{v} / \mathrm{v})$. Methylacetate, methanol and methylglyoxal (pyruvaldehyde) did not support growth at 0.1 or $0.05 \%(\mathrm{v} / \mathrm{v})$ but were not toxic at $0.05 \%(\mathrm{v} / \mathrm{v})$ in the presence of propane. Evidently $R$. rhodochrous PNKbl can metabolize the potential products of either terminal or sub-terminal oxidation of propane. 


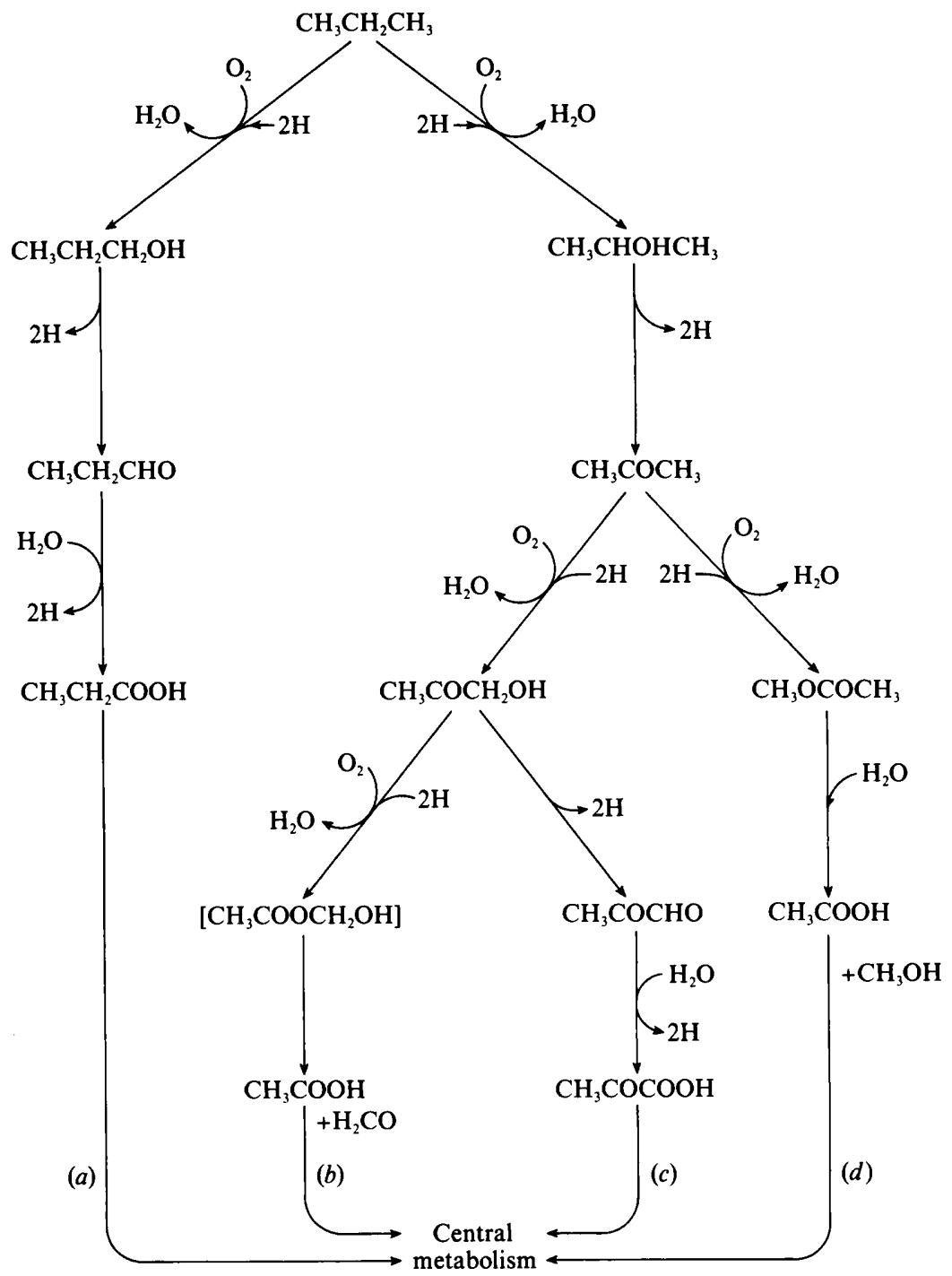

Fig. 1. Possible pathways of propane metabolism. (a) Terminal oxidation via propanoate; (b) subterminal oxidation via acetol and hydroxymethylacetate; $(c)$ sub-terminal oxidation via pyruvate; $(d)$ sub-terminal oxidation via methyl acetate.

\section{Oxidation of potential intermediates of propane metabolism by $R$. rhodochrous $P N K b 1$}

Substrate-dependent oxygen uptake was determined for propane-, propan-1-ol-, propan-2-oland pyruvate-grown cells (Table 1). It was evident that propane oxidation was inducible only by growth on propane (of the four growth substrates tested). The ability of pyruvate-grown cells to oxidize all the potential intermediates of propane metabolism tested suggested that the enzymes required for their metabolism are constitutively expressed. However, there appeared to be an increase in the levels of activity after growth on either the alcohols or the alkane. The low level of propanoate oxidation and the inability to oxidize methylacetate by propane-grown cells may be due to the lack of an uptake system for these substrates. In total these results suggest that $R$. rhodochrous PNKb1 has the metabolic potential to further metabolize both terminal and subterminal oxidation products of propane. 
Table 1. Ability of $R$. rhodochrous PNKb1 to oxidize potential intermediates of propane metabolism after batch growth on propane, propan-1-ol, propan-2-ol or pyruvate

Rates are expressed as nmol oxygen consumed $\min ^{-1}$ ( $\mathrm{mg}$ dry weight cells) ${ }^{-1}$.

\begin{tabular}{|c|c|c|c|c|}
\hline Assay substrate & Propane & Propan-1-ol & Propan-2-ol & Pyruvate \\
\hline Propane & $21 \cdot 0$ & 0 & 0 & 0 \\
\hline Propan-1-ol & $24 \cdot 6$ & $31 \cdot 3$ & $27 \cdot 1$ & $9 \cdot 2$ \\
\hline Propanal & $26 \cdot 3$ & $45 \cdot 8$ & $33 \cdot 1$ & $10 \cdot 2$ \\
\hline Propanoate & 6.9 & 43.8 & 8.5 & $2 \cdot 7$ \\
\hline Propan-2-ol & $35 \cdot 2$ & $45 \cdot 8$ & $44 \cdot 8$ & $4 \cdot 6$ \\
\hline Propanone & 41.9 & 50.0 & 20.6 & $5 \cdot 6$ \\
\hline Acetol & $12 \cdot 1$ & 50.0 & 38.8 & $33 \cdot 3$ \\
\hline Methylacetate & 0 & 0 & 0 & ND \\
\hline Methanol & 0 & 0 & 0 & ND \\
\hline Methylglyoxal & 0 & ND & ND & ND \\
\hline Acetate & $27 \cdot 7$ & 22.9 & 15.8 & ND \\
\hline Pyruvate & 6.0 & 4.8 & 0 & 22.9 \\
\hline Succinate & $5 \cdot 8$ & $4 \cdot 4$ & 0 & ND \\
\hline
\end{tabular}

ND, Not determined.

Table 2. Specific activities of enzymes in cell-free extracts of $R$. rhodochrous PNKb1 batch-grown on propane or pyruvate

\begin{tabular}{|c|c|c|}
\hline \multirow[b]{2}{*}{ Enzyme activity } & \multicolumn{2}{|c|}{ Growth substrate: } \\
\hline & Propane & Pyruvate \\
\hline Propan-1-ol dehydrogenase* & 40 & 33 \\
\hline Propanal dehydrogenase* & 14 & 3 \\
\hline Propionyl-CoA synthetase $\dagger$ & 26 & 6 \\
\hline Propan-2-ol dehydrogenase* & 185 & 49 \\
\hline Acetone oxygenase $\neq$ & 0 & 0 \\
\hline Acetol oxygenase ${ }_{\uparrow}^{\ddagger}$ & 27 & 1 \\
\hline Acetol dehydrogenase ${ }^{*}$ & 0 & 0 \\
\hline
\end{tabular}

Enzyme activities in cell-free extracts

Specific activities of key enzymes of propane oxidation in cell-free extracts of $R$. rhodochrous PNKb1 were measured after growth on propane or pyruvate (Table 2). NAD+-linked propan-1ol dehydrogenase activity showed little increase in propane-grown cells compared to pyruvategrown cells. The other enzymes of the terminal oxidation pathway, propanal dehydrogenase and propionyl-CoA synthetase, showed a fivefold increase in levels of activity in propane-grown cells compared to pyruvate-grown cells. $\mathrm{NAD}^{+}$-linked propan-2-ol dehydrogenase activity showed a fourfold increase in propane-grown cells, and acetol oxygenase activity, which was virtually absent from pyruvate-grown cells, was present in propane-grown cells. The absence of acetol dehydrogenase activity and the presence of acetol oxygenase activity would seem to rule out conversion of acetol to pyruvate, at least in cells grown under these conditions. The absence of a measurable acetone oxygenase activity is perplexing but has been noted before in several acetone utilizers (Taylor et al., 1980). More recently, Platen \& Schink (1987) and Bonnet-Smits et al. (1988) have reported that carboxylation of acetone to acetoacetate can occur in a mixed anaerobic culture and in Thiosphaera, respectively. Therefore, such a mechanism, which thus far 


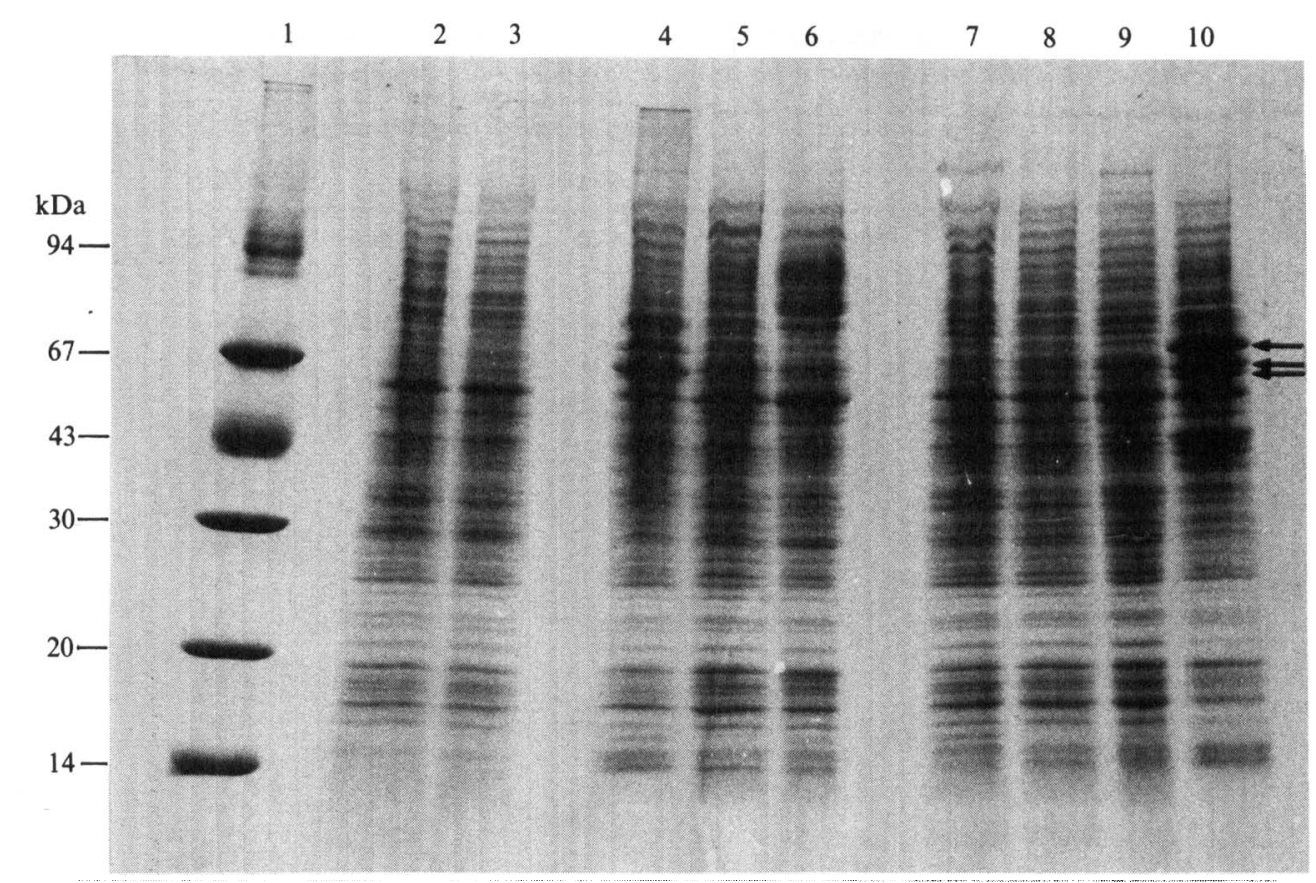

Fig. 2. SDS-PAGE of cell-free extracts of $R$. rhodochrous PNKbl grown on various potential intermediates of propane metabolism. Growth substrates were: 2 , pyruvate; 3 , succinate; 4 , acetol; 5 , acetone; 6, propan-2-ol; 7, propanoate; 8, propanal; 9, propan-1-ol; 10, propane. Track 1 contained molecular mass markers. Each track contained $50 \mu \mathrm{g}$ of protein. Arrows indicate major polypeptides specific to propane-grown cells.

has only been demonstrated in organisms capable of anaerobic growth, although unlikely, cannot be completely ruled out for the obligate aerobe $R$. rhodochrous PNKb1.

Isocitrate lyase activity appeared to be induced in propane-grown cells, suggesting a possible role for acetate in propane metabolism. The activity in propane-grown cells was $12 \mathrm{nmol} \mathrm{min}{ }^{-1}$ (mg protein $)^{-1}$, compared to zero in pyruvate-grown cells and $78 \mathrm{nmol} \mathrm{m^{-1 }}$ (mg protein) $)^{-1}$ in acetate-grown cells.

Under all growth conditions tested there was no evidence for any dye-linked alcohol dehydrogenase activity in cell-free extracts or in particulate fractions remaining after preparation of protein extracts. It should also be noted that the specific activities of all enzymes assayed for in cell-free extracts (see Table 2) did not vary significantly throughout the growth cycle of $R$. rhodochrous PNKb1 and cell-free extracts from cells harvested during early and midexponential growth had similar levels of enzyme activities to those shown in Table 2.

\section{The nature of the propane oxygenase enzyme}

Oxygenase activity was shown to be induced only during growth on propane. It appeared to have a narrow substrate range and only oxidized the short-chain unbranched $n$-alkanes ethane, propane and butane at rates of 3.8, 18.1 and $9.2 \mathrm{nmol}$ oxygen consumed $\min ^{-1}$ (mg dry weight cells) ${ }^{-1}$, respectively. Methane, isobutane, pentane, hexane and octane were not oxidized. SDSPAGE of cell-free extracts of cells grown on various intermediates of propane metabolism showed the presence of three major polypeptide bands, of apparent molecular masses 69,59 and $57 \mathrm{kDa}$, specific to only propane-grown cells (Fig. 2). These are likely to be components of the propane oxygenase system as they only appeared during induction of propane oxidation (see below).

Despite exhaustive efforts, it was not possible to measure propane-stimulated oxygen uptake or the build-up of potential intermediates of propane metabolism with cell-free extracts. 
Table 3. Effect of potential inhibitors on the formation of 1,2-epoxypropane from propene by cell-free extracts of propane-grown $R$. rhodochrous $P N K b 1$

$100 \%$ activity is $10.5 \mathrm{nmol}$ 1,2-epoxypropane formed $\mathrm{min}^{-1}(\mathrm{mg} \text { protein })^{-1}$.

$\begin{array}{lcc}\text { Inhibitor } & \begin{array}{c}\text { Concentration } \\ (\mathrm{mM})\end{array} & \begin{array}{c}\text { Relative activity } \\ (\%)\end{array} \\ \text { None } & - & 100 \\ \text { Azide } & 1 & 70 \\ & 5 & 52 \\ \mathrm{KCN} & 1 & 51 \\ & 5 & 39 \\ \mathrm{Na}_{2} \text { EDTA } & 10 & 29 \\ & 1 & 100 \\ \text { 8-Hydroxyquinoline } & 5 & 75 \\ \text { p-Hydroxymecuribenzoate } & 10 & 70 \\ \text { 2-Mercaptoethanol } & 10 & 100 \\ & 10 & 100 \\ \text { Carbon monoxide } & 1 & 100 \\ \text { Acetylene } & 5 & 90 \\ & 10 & 70 \\ & 0.5 & 100 \\ & 7.5 & 100\end{array}$

However, it was possible to measure the formation of 1,2-epoxypropane from propene, the epoxide apparently not being metabolized further. In whole-cell assays, addition of increasing amounts of propane to the assay system inhibited the formation of the epoxide, suggesting that propane and propene were competing for the same active site. NADH and oxygen appeared to be required for activity, suggesting a monooxygenase-type reaction (Colby et al., 1975). Oxygenase activity, as measured by epoxide formation, was found to be induced upon switching a chemostat culture growing on propan-1-ol to growth on propane concomitantly with the appearance of the propane-specific bands on SDS-PAGE (data not shown).

Using the formation of epoxide as a measure of oxygenase activity, the effects of various inhibitors on this activity were assayed (Table 3 ). The activity was relatively unaffected by the chelating agents EDTA and 8-hydroxyquinoline, or by the reducing effects of $p$-hydroxymercuribenzoate and 2-mercaptoethanol. Oxygenase activity was totally unaffected by the presence of carbon monoxide and acetylene but was susceptible to inhibition by cyanide. Using whole-cell suspensions an identical inhibitor profile was obtained when measuring either propanestimulated oxygen uptake in an oxygen electrode or epoxypropane formation, suggesting that epoxide formation is indeed catalysed by the propane oxygenase.

\section{DISCUSSION}

The ubiquitous nature of propane-oxidizing bacteria was demonstrated by the ease with which organisms were isolated from a variety of different terrestrial and aquatic environments. The dominance of Gram-positive organisms in both batch and continuous enrichments has been noted before (Perry, 1980; Stephens \& Dalton, 1987). $R$. rhodochrous was shown to grow on propane by Babu \& Brown (1984) and MacMichael \& Brown (1987) but the specificity of $R$. rhodochrous PNKb1 for propane alone, out of the short-chain alkanes, is unusual although not unique (Perry, 1968). The inability of alkane-utilizing species to grow on alkenes has also been frequently noted but the ability to utilize alkynes is much less well documented (Kanner \& Bartha, 1982; de Bont \& Peck, 1980).

The ability of $R$. rhodochrous PNKbl to grow on most of the potential intermediates of propane metabolism would suggest that it had the metabolic capability to utilize either the terminal or the sub-terminal pathway of propane metabolism. Previous studies (e.g. Stephens \& 
Dalton, 1986) have isolated strains of Arthrobacter with an inability to utilize specific intermediates, making the relative importance of each pathway clearer. Likewise, the oxidation of potential intermediates of propane metabolism by $R$. rhodochrous PNKb1 would suggest that the organism had the ability to use either pathway.

Elevated levels of enzyme activities in both the terminal and sub-terminal pathways in propane-grown cells would suggest that both play a role in metabolizing propane. The inability to measure acetone oxygenase activity could be due to the enzyme being extremely labile (as was the propane oxygenase) or due to a failure to achieve optimal conditions for the assay, as may have been the case with Taylor et al. (1980). The ability of the organism to grow on and oxidize acetone must indicate the requirement of an acetone-metabolizing enzyme, and the other enzyme activities present would suggest an acetone oxygenase as a likely candidate. The presence of (albeit low) levels of isocitrate lyase in propane-grown cells might suggest a role for acetate in propane metabolism, but it need not arise as an end-product of sub-terminal oxidation. Metabolism of propanoate via malonic semialdehyde could also result in cells being isocitrate lyase positive (Dagley \& Nicholson, 1970).

Assuming that the propane oxygenase enzyme was capable of producing a mixture of terminal and sub-terminal products, as indeed previously characterized alkane monoxygenase systems have been found to do (Dalton, 1980; Patel et al., 1983a), then the ability of the organism to assimilate both terminal and sub-terminal products could be an advantage and may explain the ability of $R$. rhodochrous PNKbl to do so and why such organisms are predominant in enrichment cultures on propane.

A partial purification of the propane oxygenase would answer the question of the relative carbon flow along each pathway. Attempts to purify the oxygenase from this organism were thwarted by the difficulty encountered in forming a cell-free extract (due to the extreme mechanical resistance of the cell wall) and the extreme lability of the oxygenase activity, which was not lessened despite the use of numerous stabilization agents including dithiothreitol, sodium thioglycollate and phenylmethylsulphonyl fluoride. Cells of $R$. rhodochrous PNKb1 appeared to be resistant to enzymic and chemical pretreatments to degrade their walls. Three passages through a French pressure cell at $200 \mathrm{MPa}$ were required to release cell protein and the oxygenase activity in the resulting extract had a half-life of $150 \mathrm{~min}$. The inability to measure a build-up of the products of propane oxidation prevented an estimation of the relative proportions of terminal and sub-terminal oxidation products. However, propene was epoxidated by propane oxygenase to form 1,2-epoxypropane, the build-up of which gave a good measure of oxygenase activity. The rates measured using this assay system compared favourably with the only previous report of such measurements (Patel et al., 1983b).

The effect of various potential inhibitors on this activity allowed it to be compared and contrasted with those alkane oxygenase systems most studied to date, i.e. methane monooxygenase (Dalton, 1980), octane monooxygenase from a Corynebacterium sp. (Cardini \& Jurtshuk, 1970) and octane monooxygenase from a Pseudomonas sp. (McKenna \& Coon, 1970). Of particular interest was the lack of inhibition of the $R$. rhodochrous PNKbl propane oxygenase by carbon monoxide, indicating the lack of involvement of $P_{450}$-type cytochromes. This was also confirmed by the absence of a typical CO-reduced $\mathrm{P}_{450}$ spectrum (unpublished data). This shows that the propane oxygenase system in $R$. rhodochrous PNKb1 is significantly different from that in Corynebacterium sp. 7EIC, the only alkane oxygenase system from a Gram-positive organism studied in any detail to date (Cardini \& Jurtshuk, 1970), which appeared to be $\mathbf{P}_{450}$ cytochrome linked. Lack of inhibition by the chelating agents 8hydroxyquinoline and EDTA contrasts the propane oxygenase from $R$. rhodochrous PNKb1 with that found in Pseudomonas oleovorans, which was highly susceptible to inhibition by 8-hydroxyquinoline (McKenna \& Coon, 1970). This result would suggest that any metal centres in the propane oxygenase of $R$. rhodochrous PNKb1 are tightly bound within the protein. Lack of inhibition by ethyne, which is a potent inhibitor of the soluble methane monooxygenase from Methylococcus capsulatus (Bath) shows that the enzyme in $R$. rhodochrous PNKb1 is unlike that found in the methanotrophs.

On the basis of product excretion by resting cell suspensions of $R$. rhodochrous ATCC 21198, 
Babu \& Brown (1984) suggested that the propane oxygenase from this organism was a novel intramolecular oxygenase producing mainly propan-1-ol. $R$. rhodochrous PNKbl differs from $R$. rhodochrous ATCC 21198 in that it did not oxidize isobutane or excrete propan-1-ol under any conditions. The similarity between these two oxygenase systems therefore remains unclear.

In conclusion, the relative importance of terminal and sub-terminal oxidation of propane in $R$. rhodochrous PNKbl remains uncertain. However, a cell-free assay system has been developed and future work will allow the stabilization and purification of what appears to be a novel oxygenase system, thus answering the question of the relative importance of each pathway of propane oxidation in this organism. Establishment of growth of this Rhodochrous sp. on the potential intermediates of propane metabolism will also aid future genetic analysis of the pathways of propane metabolism.

N.W.R. is grateful to the SERC and British Petroleum PLC for financial support.

\section{REFERENCES}

BABU, J. P. \& BRown, L. R. (1984). A new type of oxygenase involved in the metabolism of propane and isobutane. Applied and Environmental Microbiology 48, 260-264.

Bonnet-Smits, E. M., Robertson, L. A., Van Dijken, J. P., Senior, E. \& Kuenen, J. G. (1988). Carbon dioxide as the initial step in the metabolism of acetone by Thiosphaera pantotropha. Journal of General Microbiology 134, 2281-2289.

De Bont, J. A. M. \& PeCK, M. W. (1980). Metabolism of acetylene by Rhodococcus Al. Archives of Microbiology 127, 99-104.

CARdini, G. \& JURTShuK, P. (1970). The enzymatic hydroxylation of n-octane by Corynebacterium sp. strain 7EIC. Journal of Biological Chemistry 245, 2789-2796.

Colby, J., Dalton, H. \& Whittenbury, R. (1975). An improved assay for bacterial methane monooxygenase: some properties of the enzyme from Methylomonas methanica. Biochemical Journal 151, 459-462.

Dagley, S. \& Chapman, P. J. (1971). Evaluation of methods used to determine metabolic pathways. Methods in Microbiology 6A, 217-269.

Dagley, S. \& Nicholson, D. E. (1970). An Introduction to Metabolic Pathways. Oxford: Blackwell Scientific Publications.

DALTON, H. (1980). Oxidation of hydrocarbons by methane monooxygenases from a variety of microbes. Advances in Applied Microbiology 26, 71-87.

Dixon, G. H. \& Kornberg, H. L. (1959). Assay methods for key enzymes of the glyoxylate cycle. Biochemical Journal 72, 3-33.

GERHARDT, P. (1981). Diluents and biomass measurement. In Manual of Methods for General Bacteriology, pp. 504-507. Edited by P. Gerhardt, R. Murray, R. Costilow, E. Nester, W. Wood, N. Krieg \& G. Phillips. Washington, DC: American Society for Microbiology.

Gest, H., Dits, M. W. \& Favinger, J. L. (1983). Characterisation of Rhodopseudomonas sphaeroides. FEMS Microbiology Letters 17, 321-325.

Grunert, R. R. \& Phillips, P. H. (1951). A modification of the nitroprusside method of analysis for glutathione. Archives of Biochemistry \& Biophysics 30, 217-225.

Hartmans, S. \& DE Bont, J. A. M. (1986). Acetol monooxygenase from Mycobacterium Pyl cleaves acetol into acetate and formaldehyde. FEMS Microbiology Letters 36, 155-158.

KANNER, D. \& BARTHA, R. (1982). Metabolism of acetylene by Nocardia rhodochrous. Journal of Bacteriology 150, 989-992.

KLUG, M. J. \& Markovetz, A. J. (1971). Utilization of aliphatic hydrocarbons by microorganisms. Advances in Microbial Physiology 5, 1-43.

LAEMMLI, U. K. (1970). Cleavage of structural proteins during the assembly of the head of bacteriophage T4. Nature, London 227, 680-685.

MACMichaEL, G. \& BROWN, L. (1987). Role of carbon dioxide in catabolism of propane by 'Nocardia paraffinicum' (Rhodococcus rhodochrous). Applied and Environmental Microbiology 53, 65-69.

MCAULIFFE, C. (1966). Solubility in water of paraffin, cycloparaffin, olefin, acetylene, cycloolefin and aromatic hydrocarbons. Journal of Physical Chemistry 70, 1267-1275.

MCKenNa, E. J. \& COON, M. J. (1970). Enzymatic $\omega$ oxidation IV. Purification and properties of the $\omega$ hydroxylase of Pseudomonas oleovorans. Journal of Biological Chemistry 2A5, 3882-3889.

O'FARRELL, P. H. (1975). High-resolution two-dimensional electrophoresis of proteins. Journal of Biological Chemistry 250, 4007-4021.

Patel, R. N., Hou, C. T., Laskin, A. I., Felix, A. \& DERELANKo, P. (1983a). Oxidation of alkanes by organisms grown on $\mathrm{C}_{2}-\mathrm{C}_{4}$ alkanes. Journal of Applied Biochemistry 5, 107-120.

Patel, R. N., Hou, C. T., Laskin, A. I., Felix, A. \& Derelanko, P. (1983b). Epoxidation of n-alkenes by organisms grown on gaseous alkanes. Journal of Applied Biochemistry 5, 121-131.

PerRy, J. J. (1968). Substrate specificity in hydrocarbon utilizing organisms. Antonie van Leeuwenhoek 34, 27-36.

PerRY, J. J. (1980). Propane utilization by microorganisms. Advances in Applied Microbiology 26, 89-115.

Platen, H. \& Schink, B. (1987). Methanogenic degradation of acetone by an enrichment culture. Archives of Microbiology 149, 136-141.

ReEves, H. C., Rabin, R., Wegener, W. S. \& AJl, S. J. (1971). Assays of enzymes of the tricarboxylic acid and glyoxalate cycles. Methods in Microbiology 6A, $452-455$. 
Robinson, J. \& CoOper, R. M. (1970). Method of determining oxygen concentration in biological media, suitable for calibration of the oxygen electrode. Analytical Biochemistry 33, 390-399.

Stephens, G. M. \& Dalton, H. (1986). The role of terminal and subterminal oxidation pathways in propane metabolism by bacteria. Journal of General Microbiology 132, 2453-2462.

Stephens, G. M. \& Dalton, H. (1987). Is toxin production by coryneform bacteria linked to their ability to utilize hydrocarbons? Trends in Biotechnology 5, 5-7.

STIRLING, D. I. (1978). Oxidation of carbon compounds by Methylococcus capsulatus. $\mathrm{PhD}$ thesis, University of Warwick, UK.
Taylor, D. G., Trudgill, P. W., Cripps, R. E. \& HARRIS, P. R. (1980). The microbial metabolism of acetone. Journal of General Microbiology 118, 159170.

Van Ginkel, C. G., Welton, H. G., Hartmans, S. \& DE BoNT, J. A. M. (1987). Metabolism of trans-2butene and butane in Nocardia TB1. Journal of General Microbiology 133, 1713-1720.

Whittenbury, R., Phillips, K. C. \& Wilkinson, J. F. (1970). Enrichment, isolation and some properties of methane-utilizing bacteria. Journal of General Microbiology 61, 205-218. 